P-ISSN: 2774-4574; E-ISSN: 2774-4582 TRILOGI, 1(1), Mei-Agustus 2020 (52-60) @2020 Lembaga Penerbitan, Penelitian, dan Pengabdian kepada Masyarakat (LP3M) Universitas Nurul Jadid Paiton Probolinggo

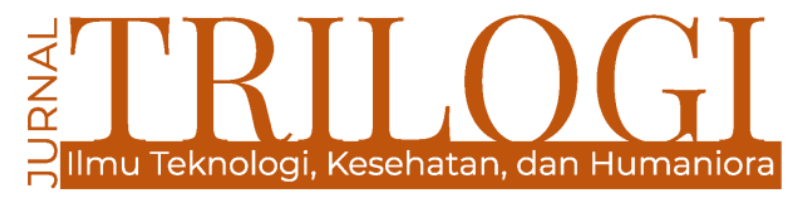

DOI: https://doi.org/

\title{
MEMASARKAN SHALAWAT: Dari Pasar Dakwah hingga Ekonomi Global
}

\author{
Nurul Huda \\ Universitas Nurul Jadid Probolinggo, Indonesia \\ kaconghuda@gmail.com
}

\begin{abstract}
This article attempts to figure out the ways the commodification strategy which is carried out by Majelis Shalawat is not only to increase the number of majelis followers, but also to take advantage of their loves in order to increase and maintain the existence of the majelis in the midst of the religious industry in Indonesia. Using the critical discourse analysis method to the religious symbols of Syubbanul Muslimin in Probolinggo, this study finds that in shalawat stage with various religious symbols, there is an unavoidable economic mechanism, a pivot point between religion and market which certainly becomes a new hope on the one side as well as a challenge on the other side in the context of a global economy. This mechanism works through the formation of space (spatialization) in the virtual realm and the real network of the da'wah market.
\end{abstract}

Keywords: majelis shalawat; da'wah market; global economy

\begin{abstract}
Abstrak
Artikel ini ingin memperlihatkan bagaimana strategi komodifikasi yang dijalankan oleh Syubbanul Muslimin itu untuk bukan hanya meningkatkan jumlah anggota majelis, melainkan juga memanfaatkan kecintaan mereka dalam meningkatkan dan mempertahankan eksistensi majelis itu sendiri di tengah industri religius yang sedang marak di Indonesia. Dengan menggunakan metode analisis wacana kritis, studi ini menemukan bahwa panggung shalawat dengan berbagai simbol religius di dalamnya, terdapat mekanisme ekonomis yang tidak bisa dihindari, suatu titik temu antara agama dan pasar religius yang tentu saja menjadi harapan baru di satu sisi sekaligus menjadi tantangan di sisi yang lain dalam konteks ekonomi global. Mekanisme itu bekerja melalui pembentukan ruang (spasialisasi) di ranah virtual dan jaringan real pasar dakwah.
\end{abstract}

Katakunci: majelis shalawat; pasar dakwah; ekonomi global 


\section{Pendahuluan}

Penceramah muda, kiai, gus, atau habaib telah menciptakan ceruk baru dalam gerakan dakwah yang berkembang di Indonesia dengan mengidentifikasi gerakan mereka sebagai melayani umat Nabi Muhammad. Banyak dari mereka telah menamai majelis shalawat mereka untuk menekankan hubungan dengan Nabi: "Syubbanul Muslimin" (Para Pemuda Muslim), "Nurul Musthofa" (Terang Yang Terpilih), "Majelis Rasulullah" (Majelis Nabi), "Ahbabul Musthofa" (Pecinta Yang Terpilih), dan "Waratsatul Musthofa" (Pewaris yang Terpilih) untuk menyebut beberapa. Majelis Syubbanul Muslimin menggunakan gambar masjid, kubah dengan logo bulan bintang, untuk logo mereka. Mereka menyatakan bahwa perhatian utama dakwah adalah mengajak umat untuk mencintai Rasulullah SAW. Mereka berpendapat bahwa untuk membuat orang berkomitmen pada iman, kaum muda Muslim harus terlebih dahulu mengenali dan menyayangi Nabi. Untuk menarik orang ke ceramah agama mereka, habaib mencoba memperkenalkan Muhammad sebagai seorang pria melalui cerita dan lagulagu Islam alih-alih berceramah tentang subjek agama yang ketat. Dengan memperkenalkan dan berceramah tentang Nabi Muhammad, habaib berharap jemaat akan menjadikan Nabi panutan dalam kehidupan duniawi mereka. Metode dakwah ini menyerupai gereja-gereja injili baru di AS, yang mengkhotbahkan kesakralan Yesus dengan mengikuti ajaran dan teladan-Nya (Stassen 2012: 51).

Kecintaan terhadap Nabi dalam majelis shalawat diungkapkan dalam ritual dan perayaan keagamaan untuk mengingat dan mengirimkan pujian kepadanya. Ritual keagamaan yang dilakukan oleh umat Muslim tradisional, seperti membacakan pujian kepada Nabi (salawatan), merayakan ulang tahun Nabi (maulid), dan mengunjungi makam orangorang kudus (ziarah) dibingkai sebagai amalan kenabian. Hal ini berbeda dengan kelompok reformis dan Salafi yang bersikeras pada emulasi ketat Nabi dalam hal praktik keagamaan dan menentang segala hal yang melanggar hukum (bid'ah) yang memmuja Nabi dalam bentuk-bentuk festival maulid dan bacaan-bacaan tekstual pujian kepada Nabi. Dalam beberapa majelis shalawat, ritual membaca teks maulid biasanya mendahului kegiatan dakwah. Setiap majelis sering merayakan perayaan maulid di area terbuka bersama ribuan peserta. Bagi para penceramah, ritual maulid dipandang sebagai sarana untuk menyenangkan Nabi. Beberapa kiai, gus, atau habaib, serta para peserta percaya bahwa roh Nabi hadir ketika teks maulid dibacakan. Dengan membacakan pujian kepada Nabi, anggota jamaah percaya bahwa mereka akan mendapatkan barokah untuk diri mereka sendiri dan keluarga mereka serta mendapatkan bantuan khusus (shafa'at)dari Nabi di akhirat terlepas dari banyak dosa mereka.

Kiai, gus, atau habaib menggunakan simbol-simbol Nabi sebagai branding dalam pemasaran keagamaan mereka. Menurut Mara Einstein (2007: 70), branding adalah tentang "memberikan sesuatu tentang produk atau layanan di luar atribut fisiknya kepada para konsumen untuk dipikirkan dan dirasakan". Di Indonesia, para penceramah umumnya merujuk pada cerita dan hadits Nabi "dengan cara-cara yang beresonansi dengan kekhawatiran sipil, keinginan konsumer, dan kesalehan aspirasional kelas menengah Muslim" (Hoesterey 2012: 38-61). Aa Gym, misalnya, ketika memberikan seminar dan pelatihan kewirausahaan, 'menggunakan' Nabi sebagai panutan pengusaha etis yang memperlihatkan sifat kesalehan, kepercayaan, dan inisiatif untuk mencapai kesejahteraan. Pembingkaian ini berusaha menunjukkan Nabi sebagai ukuran kosmopolitanisme Muslim (Hoesterey 2012: 46). Penampilan kiai, gus, dan habaib, bagaimanapun, memperlihatkan diri sebagai jalan untuk mengenali dan meniru kepribadian dan penampilan Nabi. Mereka berpendapat bahwa mengenali Nabi akan menuntun orang untuk memperdalam Islam dan menjalankan ajaran-ajarannya. Produk religius dengan berbagai simbol kenabian (nabawi) menjadi sesuatu yang menarik bagi para pengikut habaib. Bahkan, sebagian gerai ritel majelis shalawat menyebut dirinya "Kios Nabawi" (Kios Nabi). Kios ini menjual buku tentang cara mengikuti etika dan doa Nabi. Ada juga beberapa buku karya cendekiawan Hadhrami tentang teks maulid yang berisi puisi dan pujian kepada Nabi. Pemasaran barang 
dagangan tersebut merupakan bentuk dakwah dan penghasilan tersebut digunakan untuk mendukung lingkaran kegiatan majelis. Dengan mengkonsumsi produk-produk ini, orang mengidentifikasi diri mereka sebagai pengikut kiai, gus, atau habaib (muhibbin) dan Muslim saleh yang membantu memastikan kelangsungan hidup dakwah Nabi.

Mengingat habaib adalah keluarga Nabi, dan sebagian kiai dan gus merupakan keturunan walisongo, branding $\mathrm{Nabi}$ dan Walisongo dapat meningkatkan kewenangan para penceramah. Oleh karena itu, tidak mengherankan jika banyak penceramah, kiai, gus, dan habaib mengidentifikasi diri mereka memiliki silsilah dengan Nabi Muhammad atau Walisongo. Banyak kiai, gus, dan habaib menarik perhatian melalui belas kasihan dan keutamaan moral Nabi dan Walisongo. Dengan menghubungkan Nabi dengan dakwah mereka, mereka mengirimkan pesan bahwa mereka lebih dekat dengan Nabi dan Walisongo, dan bahwa mereka adalah pewaris sah Nabi dan Walisongo dalam mengkhotbahkan Islam. Untuk memperkuat legitimasi mereka di hadapan umat, beberapa kiai, gus, dan habaib menyatakan bahwa mereka telah bertemu dan menerima bimbingan dari Nabi dan Walisongo melalui mimpi dan penglihatan.

\section{Metode}

Studi ini menggunakan pendekatan pustaka (library research) yang berusaha melihat perkembangan Majelis Shalawat Syubbanul Muslimin di Kabupaten Probolinggo sebagai salah satu cermin dari bentuk spasialisasi pasar religius. Datanya bersumber dari beberapa majalah, koran, dan sebagian juga merupakan hasil observasi. Analisis yang digunakan didasarkan pada analisis wacana kritis (critical discourse analysis) Teun Van Dijk (dalam Rustandi, 2018). Terdapat tiga elemen dalam Analisis Wacana Kritis Teun Van Dijk, yaitu teks, kognisi sosial, dan konteks sosial. Teknik pengumpulan data dilakukan melalui observasi dan dokumentasi. Teknik analisis ini digunakan untuk mendalami secara kritis wacana-wacana yang berkembang seputar konstruksi majelis shalawat sebagai komoditas religius dalam pasar agama (religious market) yang memiliki kaitan dengan perkembangan ekonomi global.

\section{Diskusi dan Pembahasan \\ 3.1. Majelis Shalawat sebagai Pasar Dakwah}

Di pasar dakwah habaib yang semakin kompetitif, setiap majelis berlomba-lomba memberikan produk khas yang menarik minat konsumen Muslim muda. Gus Hafidz dari Majelis Syubbanul Muslimin, misalnya, adalah seorang kiai dan penceramah karismatik yang menggunakan gaya sastra, tulus, dan menyadarkan hati (dari hati ke hati) dalam ceramahnya. Majelis-nya juga yang terbesar dalam hal merchandising, setidaknya di Jawa Timur. Banyak pengikut yang mengklaim bahwa mereka telah menerima pengetahuan dan pencerahan setelah menghadiri shalawat Gus Hafidz. Dalam kasus Gus Hafidz dari Majelis Syubbanul Muslimin, kekuatannya terletak pada akomodasi aspirasi anak muda dan keinginan mereka yang kuat untuk hiburan. Lantunan dan nyanyian doa dari lirik yang disusun oleh Gus Hafidz menarik bagi para pengikut muda, terutama remaja. Gus Hafidz biasanya memodifikasi lagu-lagu populer Indonesia dengan mengubah liriknya menjadi lagu religius. Bagi para pengikutnya, pertunjukan musik di tengah ceramah dan shalawat lebih berwarna dan membantu mereka menghindari kebosanan saat mendengarkan penceramah. Oleh karena itu, tak heran jika banyak anggota jamaah mudanya yang lebih kagum dengan ragam keseruan dan hiburan di majelis ketimbang ceramahnya.

Popularitas majelis telah memungkinkan para pemimpin mereka untuk mengembangkan kepentingan bersama dengan para pejabat negara dan politisi. Memiliki keterkaitan dengan pejabat negara merupakan bagian dari modal sosial yang habaib gunakan dalam menjaga dan memajukan majelis mereka. Di satu sisi, kerja sama antara majelis dengan pejabat negara dan politisi membantu pendanaan dan memfasilitasi kegiatan majelis serta meningkatkan citranya bagi audiens Muslim. Staf Majelis Syubbanul Muslimin mengaku sudah ada sumbangan dari berbagai politisi dan pengusaha. Sumbangan tersebut antara lain uang dan mobil untuk operasi habaib dan majelis, serta pembayaran sewa untuk markas majelis. Baru-baru ini (04/06/2020), anggota DPR RI dari PDI Perjuangan, Mufti Anam, melaksanakan rapid test massal gratis di Pesantren Nurul Qadim, tempat Majelis 
Shalawat Syubbanul Muslimin. Dalam program itu, Mufti memfasilitasi rapid test massal untuk para santri yang datang secara bertahap. Kesehatan para santri juga diperiksa. Santri yang datang bertahap akan menjalani isolasi terlebih dahulu. Pembelajaran belum akan dimulai 14 hari setelah santri datang. Pihak Majelis Syubbanul Muslimin juga mengklaim bahwa hubungan dekat mereka dengan pejabat negara dan pemerintah daerah telah menghasilkan akses mudah ke area publik, untuk menyelenggarakan acara-acara tertentu.

Di sisi lain, para pejabat negara dan politisi menggunakan peristiwa ini sebagai sarana untuk memoles citra keagamaan mereka, terutama sebelum pemilihan. Meminjam perspektif Kertzer tentang ritual, politik, dan kekuasaan, acara keagamaan berfungsi sebagai ritual bagi "calon pemimpin politik ... untuk menegaskan hak mereka untuk memerintah, pemegang kekuasaan petahana berusaha untuk memperkuat otoritas mereka" (Kertzer 1988: 1). Mufti Anam sendiri pernah menyatakan bahwa program rapid test ini sekaligus implementasi dari gotong royong dalam spirit Juni sebagai Bulan Bung Karno. Intisari Pancasila adalah gotong royong, dan hanya dengan gotong royong kita bisa menyambut new normal dengan aman dari Covid-19 dan tetap produktif, termasuk produktif dalam pendidikan. Dalam acara keagamaan tersebut, biasanya kiai, gus, dan habaib menyebutkan nama tamu mereka, memuji kehadiran mereka, dan meminta anggota jamaah untuk mendoakan kesuksesan mereka dalam karier politiknya. Meskipun kiai, guru, dan habaib tidak mendeklarasikan dukungan politik mereka untuk kandidat tertentu, doa dan harapan baik dari kiai dan guru, serta habaib selama acara keagamaan ditafsirkan oleh audiens mereka sebagai dukungan politik.

Meningkatnya permintaan untuk ceramah publik di daerah perkotaan dan tingginya imbalan keuangan telah menguntungkan para penceramah agama melalui majelis-majelis mereka. Beberapa penelitian telah mengkonfirmasi keberhasilan penceramah dan majelis yang mereka pimpin dalam memanfaatkan pengetahuan Islam mereka di kota-kota besar (Muzakki 2007; Hoesterey 2008 \& 2016; Howell 2008; Rudnyckyj 2010; Kailani 2015).

\subsection{Spasialisasi Pasar Syubbanul Muslimin}

Kesuksesan malis shalawat Syubbanul Muslimin menurut Gus Hafidz tidak lepas dari tiga tahapan dakwah yang diajarkan gurunya sewaktu di Yaman, yaitu ta'rîf (dikenal), ta'liff (dicintai), dan terakhir baru taklif (pemberian beban). Kesuksesan da'wah bagi Gus Hafidz sangat tergantung pada dua tahapan di awal yaitu bagaimana Syubbanul Mulimin dapat dikenal dan dicintai. Untuk mensukseskan dua tahapan ini, Syubbanul Muslimin menerapkan strategi yang menurut Vincent Mosco disebut sebagai spasialisasi, yakni pemanfaatan seluruh ruang dan waktu (space) untuk memperkenalkan berbagai produk kepada pasar dengan seluas-luasnya (Mosco, 1996). Melalui spasialisasi ini Syubbanul Muslimin melakukan penawaran dengan memanfaatkan berbagai ruang-ruang pemasaran, baik virtual maupun real.

\section{a. Spasialisasi Virtual}

Menurut Lyon, salah satu pendorong utama perubahan budaya adalah perubahan bentuk bentuk komunikasi dan teknologi informasi, selain konsumerisme. Dengan menggunakan jaringan internet, komunikasi antar pengguna internet (netizen) telah melampau sekat-sekat ruang (Lyon, 2000). Meskipun Syubbanul Muslimin berada di lokasi pedesaan, melalui spasialisasi virtual (Cyberspace) telah menjadi bagian dari masyarakat global yang melampau batas-batas lokalnya.

Beberapa jejaring sosial (medsos), mulai facebook, whatsApp, hingga instagram telah menjadi media informasi, penawaran komoditas religius hingga produk-produk dagangan koperasi Syubbanul Muslimin. Informasi kegiatan dan kata-kata mutiara Gus Hafidz yang didesain banner dengan foto kegiatan, meme, hingga foto habaib dan para kiai termasuk foto Gus Hafidz sendiri disebar oleh akun resmi Syubbanul Muslimin dan para jamaahnya. Setiap unggahan di facebook dan dinstagram yang sudah memiliki 60 ribu follower, juga selalu dilike ribuan orang.

Semantara bagi yang ingin membeli jaket, kopiah, surban dan lain-lain juga bisa dilakukan secara online tanpa harus beli di tempat acara shalawatan yang selalu 
berpindah-pindah. Demikian juga dengan lagu-lagu Syubbanul Muslimin dapat diakses melalui youtube. Menurut keterangan Gus Hafidz setaip lagu yang sudah diunggah sudah dilihat ratusan ribu hingga jutaan dan disubcribe puluhan ribuan youtuber.

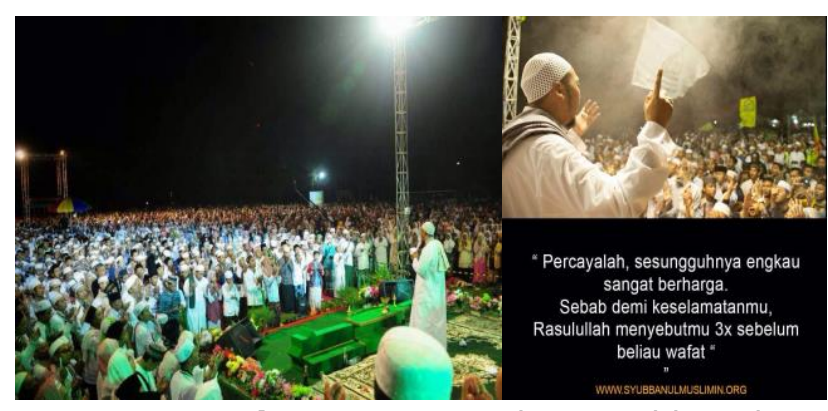

Gambar 6. Pertunjukan Syubbanul Muslimin yang Dishare melalui Facebook, WhatsApp, dan medsos lain

Selain itu, cyberspace juga menjadi ajang silaturrahim untuk mengintensifkan hubungan jamaah dengan pengurus/pimpinan majelis shalawat atau antar jamaah sendiri. Melalui cyberspace ini jamaah, pengurus dan pimpinan Syubbanul Muslimin meraskan apa yang disebut intensifikasi diasporik (Herbert, 2011). Artinya pengurus dan jamaah yang tersebar secara geografis dapat merasakan pelayanan yang sama dan kemudahan berinterkasi hingga benar-benar berada dalam suatu komunitas global. Pemanfaatan cyberspace membuat jamaah Syubbanul Muslimin yang tersebar secara geografis dapat merasakan pelayanan yang sama dan kemudahan berinterkasi secara intensif hingga benar-benar berada dalam suatu komunitas global.

\section{b. Spasialisasi Jaringan Real}

Selain melalui cyberspace, spasialisasi Syubbanul Muslimin di dunia real dibantu jaringan alumni dan simpatisan Pondok Pesantren Nurul Qodim. Dengan pengurus sebesar 250 orang ditambah koordinator desa (koordes) yang terdapat di setiap desa, informasi kegiatan-kegiatan Syubbanul Muslimin mudah menyebar. Koordinasi dan mobilasasi berjalan begitu efektif dan massif hingga dalam setiap penyelenggaraan shalawatan selalu dihadiri puluhan ribu jamaah. Sampai saat ini popularitas Syubbanul Muslimin hingga saat ini masih yang tertinggi, hingga ke luar kota Problolinggo, seperti banyuwangi, Madura, Situbondo, Malang dan lain sebagianya.

Pemanfaatan jaringan alumni dan simpatisan pesantren Nurul Qodim, sangat mudah dikonsolidasikan mengingat Gus Hafidz juga seorang putra salah satu pengasuh pesantren tersebut. Dalam masyarakat tradisional, seorang gus dapat disebut ascribed status, karena kedudukannya yang terhormat diperoleh secara otomatis karena faktor keturunan. Seorang kiai bagaikan raja kecil dan gus ibarat pangiran kecil yang dianggap terlahir dengan kedudukan dan hak-hak istimewa. Bila dalam masyarakat religius seorang kiai diidentikkan dengan ulama' yang dalam ajaran Islam disebut pewaris kenabian, maka seorang gus adalah calon ulama'.

Menurut Pierre Bourdieu seseorang yang berada dalam puncak strata seperti gus dapat membentuk prilaku manusia yang disebut habitus (Harker, dkk., 2009). Prilaku keagamaan seperti shalawatan baik secara sadar maupun tidak menurut teori Bourdieu dapat menjadi tradisi keagamaan suatu komunitas tertentu apabila dibentuk oleh seseorang yang memiliki strata tertinggi dalam struktur sosial tertentu. Ungkapan ini ada benarnya, mengingat faktanya Syubbanul Muslimin yang didirikan oleh Gus Hafidz begitu mudah mendapatkan dukungan dari masyarakat luas apalagi di kalangan santri dan alumninya.

Kendati demikian, shalawatan yang diperkenalkan oleh Syubbanul Muslimin tidak sepenuhnya berasal dari ide Gus Hafidz yang menurut teori Bourdieu dapat menciptakan habitus. berdasarkan keterangan Gus Hafidz, kegiatan shalwatan tersebut dipilih oleh anggota majelis sendiri yang terdiri dari para pemuda sebagai pembeda dengan kegiatan rutin keagamaan seperti, yasinan, istighosah, manaqiban dan lain-lain (Wawancara dengan Gus Hafidz, Ketua Majelis Syubbanul Muslimin, 24/07/2017). Dari sini ternyata shalwatan merupakan hasil konsensus. Sementara juga banyak majelis-majelis dzikir meskipun didirikan oleh seorang gus tidak begitu mendapatkan respon di masyarakat apalagi di kalangan pemuda. 
Kenyataan tersebut, menunjukkan bahwa suatu kegiatan keagamaan yang diawarkan oleh seorang Gus tidak begitu saja diterima oleh suatu komunitas sosial. Menurut Anthony Gidden seorang individu (agen) memang dapat mempengaruhi struktur dengan kemampuannya, tetapi struktur juga dapat mengikat dan menggerakkan agen dengan kuatnya. Tidak ada pihak yang paling dominan yang dapat mempengaruhi salah satunya. Relasi ini biasanya disebut sebagai dualitas, yaitu suatu hubungan timbal balik dan saling mempengaruhi satu sama lainnya (Mosco, 1996).

Sebagai bagian dari agen, seorang gus mempunyai peluang cukup besar untuk mempengaruhi struktur masyarakat luas. Melalui modal sosial dan keilmuan yang memadai, seorang gus dapat menjadikan dirinya sebagai agen yang berpengaruh. Tetapi struktur dibentuk bukan sematamata karena determinasi agen, melainkan karena ada relasi, interaksi dan konstribusi dari berbagai pihak dalam sebuah struktur sosial, bahkan legitimasi negara. Dalam hal ini, media, negara dan publik berada dalam ruang dan waktu yang sama untuk melakukan interaksi. Berdasarkan prespektif ini, shalawatan merupakan hasil dari interaksi berbagai pihak yang tidak terpisahkan antara satu dengan yang lain.

Oleh sebab itu, seorang gus yang menjadi pimpinan tertinggi sebuah majelis shalawat, tidak cukup hanya bermodal strata dan keilmuan saja. Untuk mendapatkan kepercayaan publik, ia harus benar-benar memiliki kepribadian dan perilaku yang sesuai dengan pandangan positif publik, mulai dari pengurus hingga masyarakat luas. Mekipun tidak mungkin mengimplementasikan seluruh selera dan keinginan publik, setidaknya ia menjadi seseorang yang sesuai dengan kemauan mayoritas. Dalam konteks ini, seorang gus atau agen spiritual dituntut untuk melakukan rasionalisasi terhadap pesanpesan dan perilakunya hingga dimengerti dan diterima publik.

Menurut Giddens, yang dimaksud rasionalisasi adalah tindakan seorang agen dalam melakukan motivasi-motivasi yang melibatkan keinginan dan hasrat ke ranah publik. Dalam terminologi strukturasi, keinginan/motivasi tersebut diistilahkan sebagai monitoring reflectif (Syahputra, 2013). Seorang agen seperti Gus hafidz harus senantiasa merasionalisasikan pesan-pesan religiusnya kepada publik lewat berbagai tindakan. Jika rasionalisasi dan refleksivitas ini terus menerus dilibatkan, maka publik secara perlahan akan termotivasi lebih sesuai dengan "kemauan" agen tersebut.

Rasionalisasi tersebut telah menjadi faktor penting keberhasilan spasialisasi Syubbanul Muslimin. Berdasarkan pengakuan salah satu jamaah Syubbanul Muslimin, bahwa sosok Gus Haidz dikenal sangat egaliter. Ia tidak memposisikan dirinya sebagai satu-satunya seorang agen religius yang berada di puncak strata. "Dalam keadaan hujan, shalawatan tetap berlangsung, sementara Gus Hafidz turun dari panggung berkumpul dengan para jamaah hingga sama-sama basah terkena guyuran hujan," demikian yang dikatan Muhammad Su'eb, anggota Majelis Syubbanul Muslimin (27/07/2019). Tindakan ini tentu bagian dari rasionalisasi pesan-pesan itu sendiri dengan media perilaku atau dalam istilah agama di sebut dakwah bil hâl.

Sebagai konsekuensi logis keberhasilan proses spasialisasi Syubbanul Muslimin, majelis shalawat ini sampai pada tujuan akhir yang dikehendaki yakni pemberian beban (taklîf). Dalam rentang waktu mulai 2005 hingga 2017, majelis shalawat ini telah mampu menanamkan nilai-nilai pengabdian sebagai bentuk kesalehan. Tidak ada satupun baik pimpinan maupun ratusan pengurus yang dibayar dengan materi. Mereka yakin bahwa dengan mengabdi pada majelis shalawat, mereka memperoleh keutamaan-keutamaan membaca shalawat sebagaimana yang terdapat dalam haditshadits nabi.

Keyakinan pengurus juga mulai tertanam di hati para jaamah Syubbanul Muslimin. Hal ini bisa dilihat dari pengorbanan jamaah untuk sampai pada tempat acara shalawatan. Subsidi dari majelis untuk alat transportasi yang mereka gunakan terus dikurangi. Gus Hafidz mengatakan, "Sekarang besaran subsidi yang asalnya 60 ribu untuk tiap 
mobil, tetapi kini hanya 25 ribu dan ke depan akan terus diperkecil hingga nol rupiah" (Wawancara dengan Gus Hafidz, Ketua Majelis Syubbanul Muslimin, 27/07/2017). Sebagai gantinya mereka rela mengeluarkan uang iuran untuk transportasi yang mereka gunakan. Sebagian jamaah tidak lagi datang dengan alasan diajak temen atau hanya mencari mencari hiburan, lebih dari itu merasa telah mendatkan hidayah. Salah satu jamah, Shalehuddin (40) mengatakan, bahwa ia hadir bukan "karena diajak siapapun, melainkan karena hidayah" (Wawancara dengan M. Shalehuddin, anggota jamaah Majelis Syubbanul Muslimin, 27/07/2017). Pengakuan ini meski hanya sebagaian kecil tetapi sudah cukup membuktikan kekeliruan sebagian orang yang menganggap shalawatan hanya hiburan semata.

\subsection{Relasi Majelis Shalawat dengan Pemasaran Ekonomi Global}

Fenomena tumbuh suburnya majelis shalawat seperti Syubbanul Muslimin belakangan ini, menunjukkan bahwa reaksi agama terhadap modernitas tidak selamanya dalam posisi yang secara umum bertentangan sebagaimana pengalaman Barat. Fenomena popularisasi shalawatan membuktikan bahwa menjadi modern tidak mesti meninggalkan agama atau untuk menjadi umat beragama yang baik tidak pula harus mengisolasi dari dari modernitas. Artikulasi umat beragama yang ditandai dengan hadirnya shalawatan dalam ranah publik dengan memanfaatkan desain dan sarana modern, mendestabilisasi narasi modernitas sebagaimana didefinisikan dengan kemunduran peran publik agama.

Dari sini, menjadi penting untuk membedakan "agama" sebagai cara khas kehidupan masyarakat umat beragama yang dibentuk oleh sistem keyakinan yang berorientasi pada spiritual semata dan "agama" sebagai artikulasi yang lebih secara signifikan berubah saat menyebar di seluruh permukaan kehidupan sosial (Herbert, 2011). Melihat proses perkembangannya Shalawatan adalah salah satu contoh yang dproduksi melalui artikulasi agama. Perkembangan shalawatan yang semula hanya sebagai ungkapan pujian kecintaaan ke pada nabi dengan kalimat sederhana, kemudian terus diinterpretasi hingga tercipta puluhan karya shalawat. Akhirakhir ini shalawat kembali hadir dengan wajah yang sesuai dengan interpratasi tempat dan zaman sekarang.

Pada zaman sekarang shalawatan tidak saja menunjukkan wajah spiritualnya, melainkan juga sebagai kegiatan yang menghibur dan menyenangkan. Popularisasi shalawat ini melengkapi trend komersialisasi religius yang menunjukkan ciri kebangkitan keagamaan kontemporer. Salah satu ciri penting perkembangan agama kontemporer adalah kemampuan adapatasinya dengan ekonomi pasar global yang lebih menekankan aspek penawaran religusitas daripada sisi permintaan. Religuisitas seperti ritual, ritus, tokoh-tokoh agama, simbol-simbol syariah kian diproduksi secara massal dalam pasar spiritual. Sehingga shalawatan yang bersifat lokal di saat yang sama mengalami glokalisasi, yang privat mengalami deprivatisasi/publikasi, yang original mengalami sinkretisasi, dan yang terbatas pada teritorial tertentu mengalami deteritorialisasi atau hibridasi.

Penekanan sistem penawaran sebagai ciri globalisasi agama tersebut dalam pembahasan sebelumnya disebut disneyisasi. Menurut Alan Bryman, proses disneyisasi meliputi empat elemen, yakni theming, dediferentiantion of consumption, mechandising, dan emotional labour (dalam Lyon, 2000). Theming berfungsi menciptakan koneksi dan dengan demikian memberi suasana tertentu pada lingkungan yang komplit. Even-even religius akan terasa relevan dan kontekstual bila terdapat tematema tertentu yang berhubungan dengan harihari besar, tempat, dan komonitas-komonitas tertentu. Penyelenggaraan Syubbanul Muslimin selalu kontekstual karena selain ada lagu-lagu baru dalam setiap penyelenggaraan, terdapat juga tema yang selalu berbeda-beda, seperti Kraksaan bershalawat, ulang tahun anak embongan, berkurban untuk meraih cintanya, takbir akbar bersama Syubbanul Muslimin, dan lain sebagainya.

Selanjutnya dedifferentiantion of consumption, adalah istilah teknis yang mengacu pada cara-cara bentuk konsumsi yang berbeda tapi saling terkait satu sama lain dan semakin sulit untuk dibedakan. Even-even religius seperti shalwatan semakin tidak bisa dibedakan apakah untuk konsumsi spiritual atau hanya mencari hiburan, atau malah datang hanya untuk belanja membeli bermacam- 
macam atribut majelis shalawat Syubbanul Muslimin. Even shalwatan telah menyediakan paket yang lengkap, spiritual, hiburan, dan tempat belanja.

Sementara itu, merchandising memainkan peranan penting dalam mempromosikan segala bentuk komoditas dengan memanfaatkan gambar dan logo. Dalam hal ini gambar dan logo Syubbanul Muslimin yang terdapat dalam setiap produk seperti kopiah, shal/surban, air mineral, album vcd dan lain sebagainya, telah meningkatkan daya jualnya. Sebagian jamaah Syubbanul Muslimin tentu tidak benar-benar merasa butuh kopiah, tetapi tetap membeli karena terdapat logo Syubbanul Muslimin.

Terakhir adalah emotional labour yang berfungsi membangun suasana tertentu melalui ekspresi para pekerja (pengurus). Ekspresi berupa senyum, sapa, dan salam sudah lumrah dimana-mana dan dipraktekkan oleh para karyawan toko, minimarket, hingga supermarket. Begitu juga dengan para pengurus Syubbanul Muslimin, sebagai komonitas religius mereka telah menunjukkan kesan penuh keihklasan dan istiqomah melebihi para jamaah. Slogan "istiqomah tanpa batas" adalah nilai yang menggambarkan pengabdiannya terhadap majelis shalawat.

Saat ini, di mana seluruh penjuru internasional telah menjadi arena pasar, selalu menuntut adanya persaingan untuk tetap eksis. Majelis-majelis shalawat sebagai produsen religius, tentu eksistensinya sangat tergantung pada kekuatan finansial. Syubbanul Muslimin membuktikan dirinya terus eksis dan mampu berkembangan dengan baik karena finansial yang memadai. shalawat sebagai komoditas menjadi tidak bisa dihindari bila suatu majelis shalawat ingin tetap bertahan. Disadari atau tidak, shawatan hari ini bagian dari seni pertunjukkan yang tentu dikontestasikan dengan berbagai jenis-jenis dunia hiburan lainnya.

Menurut David Herbert, bahwa media, format kegiatan keagamaan dan hiburan memiliki kaitan yang sangat erat, sehingga memungkinkan kelompok keagamaan (seperti majelis shalawat) memerlukan sumber daya yang cukup untuk mempertahankan dan mengembangkannya (Herbert, 2011). Dengan demikian penyelenggaraan Syubbaul Muslimin yang dikemas secara manarik dan menyenangkan hingga membutuhkan finansial yang memadai, sehingga penawaran yang berujung pergeseran nilai guna shalwat menjadi nilai tukar menjadi keniscayaan.

\section{Penutup}

Maraknya majelis-majelis shalawat itu memperlihatkan bahwa ada antusiasme yang masih berkembang di kalangan komunitas Muslim untuk mengekspresikan kecintaan mereka kepada Rasulullah Saw. Uniknya, majelis-majelis itu memanfaatkan dan meningkatkan antusiasme itu melalui berbagai strategi marketing dan promosi yang juga luar biasa. Salah satunya adalah menggunakan media baru (new media) berupa Internet untuk meningkatkan jumlah anggota jamaah majelis (followers).

Tidak mengherankan jika berbagai studi membuktikan bahwa terdapat hubungan yang tidak terpisahkan antara majelis shalawat, demam panggung, media baru, dan antusiasme kalangan komunitas Muslim di Indonesia terhadap simbol-simbol keagamaan. Karena media yang digunakan merupakan media online yang relatif populer di kalangan kaum kelas menengah, majelis-majelis itu akhirnya menjelma sebagai suatu industri keagamaan yang memanfaatkan kecintaan kaum milenial Muslim kelas menengah untuk mencapai tujuan dan visi misi mereka.

Salah satu majelis shalawat yang cukup terkenal di Kabupaten Probolinggo adalah Majelis Syubbanul Muslimin yang didirkan oleh Gus Hafidz di Kalikajar Paiton Probolinggo. Majelis ini mampu menarik perhatian para pemuda Muslim kelas menengah yang justru rata-rata hidup di desa-desa dan daerah pelosok di Probolinggo untuk terlibat dalam jejaring online yang disediakan oleh majelis tersebut, seperti Facebook, Twitter, Instagram, hingga Youtube. Channel resmi Syubbanul Muslimin yang memiliki lebih dari 2,31 juta Subscriber menunjukkan bahwa majelis ini patut diperhitungkan dalam jejaring majelis hadramaut di Indonesia.

Artikel ini telah memperlihatkan bagaimana strategi komodifikasi yang dijalankan oleh Syubbanul Muslimin itu untuk bukan hanya meningkatkan jumlah anggota majelis, melainkan juga memanfaatkan kecintaan mereka untuk meningkatkan dan mempertahankan eksistensi majelis itu sendiri di tengah industri religius yang sedang marak di Indonesia. Di tengah meningkatkan ortodoksi 
terhadap simbol-simbol religius di Indonesia, menganalisis strategi komodifikasi ini menjadi penting dilakukan untuk memperlihatkan bahwa di balik gegap gempita panggung shalawat dengan berbagai simbol religius di dalamnya, terdapat mekanisme ekonomis yang tidak bisa dihindari, suatu titik temu antara agama dan pasar religius yang tentu saja menjadi harapan baru di satu sisi sekaligus menjadi tantangan di sisi yang lain.

\section{Daftar Pustaka}

Einstein, M. (2008). Brands of Faith: Marketing Religion in Commercial Age. London and New York: Routledge.

Harker, R., Mahar, C., \& Wilkes, C. (eds). (2009). (Habitus $\times$ modal) + Ranah $=$ Praktik, Pengantar Paling Komprehensif kepada Pemikiran Pierre Bourdieu. Yogyakarta: Jalasutra.

Herbert, D.E.J. (2011). "Theorizing Religion and Media in Contemporary Societies: An Account of Religious 'Publicization'." European Journal of Cultural Studies, 14(6), 626-646.

Hoesterey, J.B. (2012). "Prophetic Cosmopolitanism: Islam, Pop Psychology, and Civic Virtue in Indonesia". City and Society, 24(1), 38-61. DOI : $10.1111 / \mathrm{j} .1548-$ 744X.2012.01067.x

Hoesterey, J.B. (2016). Rebranding Islam: Piety, Prosperity, and A Self-Help Guru. California: Stanford University Press. DOI : $\underline{10.1355 / \mathrm{sj} 32-2 \mathrm{~m}}$

Hoesterey, James B. (2008) "Prophetic Cosmopolitanism: Islam, Pop Psychology, and Civic Virtue in Indonesia," City \& Society, Vol. 24, Issue 1 , hlm. 38-61.

Howell, J. (2008). "Modulations of Active Piety: Professors and Televangelists as Promoters of Indonesian Sufism". In G. Fealy \& S. White (eds.), Expressing
Islam: Religious Life and Politics in Indonesia (pp. 63-85). Singapore: Institute of Southeast Asian Studies.

Howell, Julia Day. "Introduction: Sufism and Neo-Sufism in Indonesia Today", Review of Indonesian and Malaysian Affairs, Vol. 46, No. 2, 2012, hlm. 124.

Kailani, N. (2015). Aspiring to Prosperity: The Economic Theology of Urban Muslims in Contemporary Indonesia. PhD thesis, University of New South Wales.

Kertzer, D.I. (1988). Ritual, Politics, and Power. New Haven and London: Yale University Press.

Lyon, D. (2000). Jesus in Disneyland: Religion in Postmodern Times. UK: Polity Press, Cambridge

Mosco, V. (1996). The Political Economy of Communication. Singapore: SAGE Publications Asia-Pacific.

Muzakki, A. (2008). "Islam as a Symbolic Commodity: Transmitting and Consuming Islam through Public Sermons in Indonesia". In P. Kitiarsa (ed.), Religious Commodifications in Asia: Marketing God (pp. 205-219). London and New York: Routledge.

Rudnyckyj, D. (2010). Spiritual Economies: Islam, Globalization, and the Afterlife of Development. Ithaca: Cornell University Press. DOI : 10.1355/cs33$\underline{1 j}$

Rustandi, R. (2018). Analisis Wacana Kritis Komodifikasi Daí dalam Program Televisi. Communicatus: Jurnal IImu Komunikasi, 2(2), 197-222.

Stassen, G.H. (2012). "God's Vision for the Church-Kingdom Discipleship". In Gushee, D.P. (ed.). A New Evangelical Manifesto: A Kingdom Vision for the Common Good (pp. 50-56). St. Louis, Mo.: Chalice Press. 